\title{
TOURISTS' VALUES AND PERCEIVED APPROPRIATE USES OF NATIONAL PARKS
}

\author{
SEYED AHMAD MOUMEN GHAZVINI,* DALLEN J. TIMOTHY,†‡ JOÃO SARMENTO,§ \\ AND LAY KIAN LIM*
}

*Department of Tourism Management, Universiti Teknologi MARA, Shah alam, Selangor Darul Ehsan, Malaysia

†School of Community Resources and Development, Arizona State University, Phoenix, AZ, USA $\ddagger$ School of Tourism and Hospitality, University of Johannesburg, Johannesburg, South Africa $\S$ Geography Department \& Communication and Society Research Centre, University of Minho, Guimarães, Portugal

\begin{abstract}
National park managers must consider people's different values, beliefs, and attitudes in developing management plans and policies to justify providing opportunities for public recreation preserving ecological integrity. This study examines tourists' perceptions of appropriate uses of, and services within, national parks, which in turn are influenced by their value orientations. It then investigates how value orientations can affect tourists' perceptions toward appropriate uses of national parks. The article also identifies the mediating role of environmental concern on value orientations with regard to appropriate national park uses and services. Data from 379 tourists in Malaysia's Taman Negara National Park reveal that tourists perceive appreciative or passive activities as most appropriate and more consumptive activities, such as hunting and golf courses, as least appropriate. Results also indicate positive and negative relationships between value orientations and perceived suitableness of accommodations and services, activities, and facilities within national parks.
\end{abstract}

Key words: Ecotourism; Value orientations; Ecological attitudes; Environmental concern; Appropriate use; National parks; Malaysia

Introduction

Tourism is multifaceted and subject to quick and challenging growth within a dynamic world. Tourism is the mainspring of regional development in many countries and generates income and employment (Suttikun, Chang, Komolsevin, \& Chongsithiphol, 2015). There is strong competition among countries to attract tourists owing to their economic importance (Crespo, Simões, \& Duarte, 2016). Creating 
balance between protecting natural resources and economic development is a significant and challenging task (Alipour, Olya, \& Forouzan, 2017). Sustainable tourism advantages local residents while benefiting the environment and tourists. Using natural areas as attractive places for tourism without damaging them is a significant part of sustainable tourism. Responsible tourism entails respect for local customs and cultures, low-impact use of natural resources, involvement of stakeholders in developing tourism, creating equitable and sustained revenue for as many population segments as possible, and teaching stakeholders about their roles in preserving protected landscapes (Drumm \& Moore, 2002).

For the last two decades, variations have occurred in the evolution of ecotourism. From an economic development viewpoint, natural area visitation is a tool for job creation in traditionally underdeveloped regions or in areas where there has been a notable decline in employment in traditional industries. Resource management and conservation experts have also suggested that ecotourism can benefit conservation by providing funding for protection, interpretation, and appreciation among local residents (Nair \& Azmi, 2008).

It has been suggested that providing services and facilities within protected areas strongly affects visitors' satisfaction and experiences (Taplin, Rodger, \& Moore, 2016). There are pressures on most national parks worldwide to accommodate increasingly diverse activities and provide more facilities (Frost \& Hall, 2009). National parks must also accommodate visitors and increase overnight accommodations while trying to preserve the integrity of their resources (Ramkissoon \& Mavondo, 2017) and at the same time offering societal and personal health benefits (Hassell, Moore, \& Macbeth, 2015). If an activity is potentially harmful to the environment or may compromise the ecological integrity of a national park, it would be considered inappropriate in most cases. As a result, visitors play an important role in preserving the ecological integrity of national park resources (Wilkinson, 2003).

Egoistic, altruistic, and biospheric values underlie many tourists' value orientations. These values can originate environmental beliefs, intentions, and behaviors (Ghazvini, Lim, \& Sarmento, 2016).
Therefore, it is crucial for national park managers to comprehend tourists' value orientations and perceptions of the appropriate use of natural resources. With increasing concerns about environmental degradation, the Malaysian government and other stakeholders have raised the value of ecotourism and enhanced its managing and planning. Nonetheless, inadequacies remain that do not reflect the values and principles of sustainable nature-based tourism (Jaini, Anuar, \& Daim, 2012).

There is a significant body of research on the effects of value orientations on protected area management. Particularly prevalent are studies on environmental values and public support for both tourism and conservation in protected areas, tourists' behaviors, and perceptions of appropriate uses (e.g., Clement \& Cheng, 2011; Haukeland, Daugstad, \& Vistad, 2011).

Rossi, Byrne, Pickering and Reser (2015) realized that values significantly influence visitors' perceptions about in-park activities and their encounters with other park users. Because of their environmental values, most participants viewed motorized activities and overcrowding adversely, potentially causing conflict with others. Research by Borrie, Freimund, and Davenport (2002) found that different value orientations translated into varying levels of support for, or opposition to, management actions at Yellowstone National Park. Similar work by Alazaizeh, Hallo, Backman, Norman, and Vogel (2016) in a national heritage park in Jordan examined the importance of values in tourists' preferences toward various management actions. Imran, Alam, and Beaumont's study (2014) shed light on how different stakeholders' value orientations lead them to engage in ecologically responsible behavior in a national park setting in Pakistan.

While the discussion above demonstrates growing interest in visitors' value orientations and the effects of these on support for tourism, management actions, other users, and in-park activities, empirical research on tourists' value orientations and perceptions toward appropriate services in, and uses of, national parks is scarce, particularly in developing countries such as Malaysia. This study addresses this lacuna, and its purpose is threefold. First, it identifies visitors' perspectives on appropriate uses of national parks. Second, it scrutinizes the relationship between visitors' value orientations 
and perceptions of appropriate services, facilities, and recreational activities in national parks. Finally, it investigates how environmental concern mediates the relationship between value orientations and appropriate national park uses. In line with these objectives, this study hypothesizes:

H1: There is a significant relationship between value orientations and perceptions of appropriate uses of, and services within, national parks.

H2: Environmental concern mediates the relationship between value orientations and perceptions of appropriate uses of national parks.

\section{Structure of Value-Belief-Norm Theory}

This research is based on the value-beliefnorm theory (Fig. 1). This suggests a sequence of five causal variables that induce specific behavior (Stern, Dietz, Abel, Guagnano, \& Kalof, 1999). The starting point of the sequence is personal values, which are based on personality and advance across a centralized set of beliefs. The beliefs complex includes ecological worldview, which engages the connection between people and the natural world, the awareness of outcomes regarding human conduct, and a person's responsibility for taking action. One logical reason for the aforementioned causal relationship is that a value orientation employs a conceptually driven process (top-down), which in fact influences people to choose and advocate for value-congruous information and to refuse information that is incongruous with their value orientation (Hansla, 2011). This focused belief system vitalizes personal norms and induces a sentiment of ethical commitment to conduct oneself in a particular way. Personal norms in turn generate a general predisposition that can determine an individual's behaviors (Johansson, Rahm, \& Gyllin, 2013).

Each variable in the model directly affects the subsequent variable. Behavior is directly determined by personal norms, and each of the other variables in the chain may indirectly affect behavior via the norms (López-Mosquera \& Sánchez, 2012; Nordlund \& Garvill, 2002; Stern et al., 1999). Attitudinal factors, contextual factors, personal capabilities, and habits or routines are the most important causal factors that may impact proenvironmental behavior. Values, beliefs, and norms represent attitudinal factors. Rewards, accessibility of technology, and material costs characterize contextual factors. Skills and knowledge regarding specific behavior along with financial resources symbolize personal capabilities, while the fourth factor implies that some practices might require modification to lead actions toward more proenvironmental behavior. There may also be interactions between these casual factors (Nordlund \& Garvill, 2002; Stern, 2000).

Inspection of Values, Attitudes, and Ecological Conduct

Ajzen (1991) argued that personal intention is a central factor and entraps motivational factors that

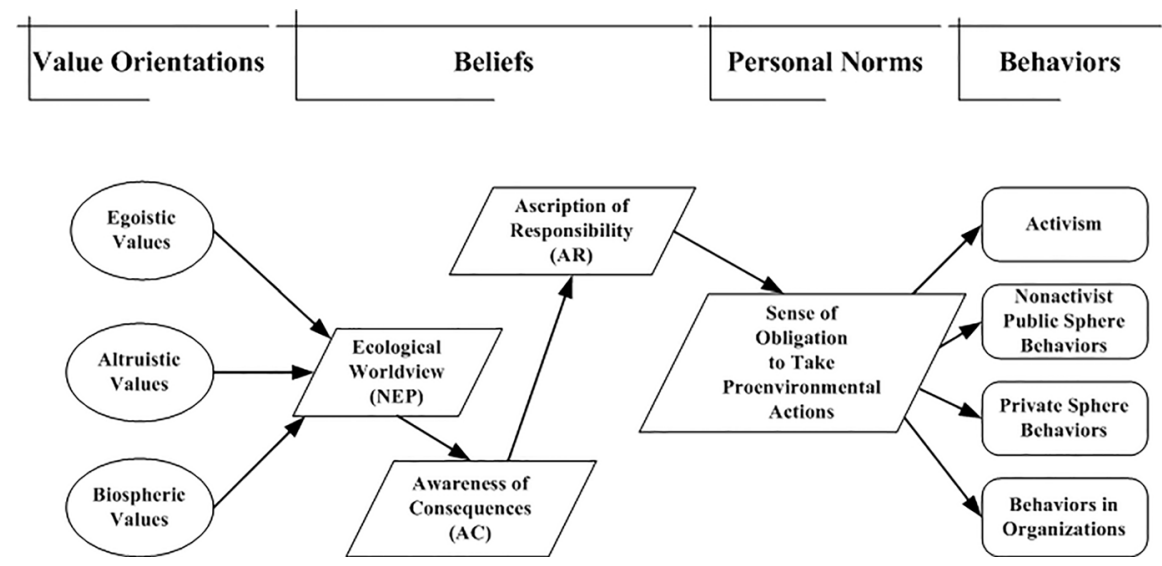

Figure 1. Variables in the value-belief-norm theory of environmentalism (modified from Stern, 2000; Stern et al., 1999). 
affect behaviors. There are three determining factors of intention:

1. Attitude toward a behavior related to an individual's degree of positive or negative assessment about particular behavior.

2. Subject norm relates to a person's perception of social force, about carrying out a behavior or not.

3. Perceived behavioral control is connected to an individual's identification of performing the behavior from previous experience, whether it is easy or difficult, and predicts barriers.

Fransson and Garling (1999) argued that personal responsibility, knowledge, and positive control beliefs or internal control can influence people's behavior. Dunlap, Grieneeks, and Rokeach (1983) noted that derivation of environmental problems comes from human values. Attitudes and values guide people's behavior, and they do in fact establish real behavior. As people mature, they learn these values and attitudes by socializing into a specific position (Uyeki \& Holland, 2000). Research shows that perceived value has a significant effect on tourists' satisfaction and their future behavioral intentions (Bajs, 2015). Recreational activities that result in positive feelings allude to leisure preferences in which values can have a significant influence on leisure behavior (Lee, Yi, Walker, \& Spence, 2017).

Environmental and social psychology studies have identified a link between ecological behavior, opinions regarding specific actions, and values (e.g., Gärling, Fujii, Gärling, \& Jakobsson, 2003; Oreg \& Katz-Gerro, 2006; Thøgersen \& Ölander, 2002). Nordlund and Garvill (2002) and Thøgersen and Ölander (2002) argued that self-enhancement (such as egoistic) versus self-transcendent (such as altruistic and biospheric) dimensions are associated with various kinds of environmental behaviors and diverse beliefs, because environmental behavior usually results in contention between long-term communal interests and instant individual benefits. Perkins and Brown (2012) found that, contrary to egoistic values, there is a strong connection among biospheric values, obligation to protecting the environment, and intense interest in ecotourism.

Environmental behavior is affected by values through attitudes, behavior-specific beliefs, and norms. Personal norms, which derive from values, turn to personal anticipation; in other words, moral obligations drive people's environmental conduct. Personal norms undoubtedly have some intersections with social norms (Gärling et al., 2003; Schwartz, 1977; Steg, Dreijerink, \& Abrahamse, 2005). Nordlund and Garvill (2003) stated that a person's value orientations are salient indicators of his/her cognizance of environmental problems. They also realize a positive correlation between self-transcendent values and personal norms along with the mediating role of personal norms on the relationship between values and readiness to lessen personal car use.

\section{Approaches in National Parks}

Many observers believe that limitations on human use, including tourism, are unnecessary or unjustified. Levels of use and types of activities are not the only determiners of impact; values, behaviors, beliefs, and attitudes of community members and visitors also determine impacts. Tourists who participate in more appreciative activities are more environmentally concerned, are more beneficial for host regions, and use nature more carefully (Bimonte \& Faralla, 2015).

Park administrators must involve community members and other stakeholders, particularly because of the differences in values, beliefs, and behaviors of a diverse population. Park policies in each country are a reflection of changing global attitudes toward protected areas. In addition, public policy tends to mirror the dominant values, norms, and beliefs of a society at any given time (Clark, Willard, \& Cromley, 2000).

National park managers must strike a balance between providing leisure public space while simultaneously conserving the environment (Swinnerton, 1999). For many years, these two goals were deemed incompatible; over the years, preservation was stressed over encouraging visitation. There are two significant reasons for this. First, growing numbers of visitors to national parks and the expanding infrastructure to facilitate their visits are exacting pressure on parkland ecosystems and surrounding areas. Secondly, with growing concerns about the planet's susceptible biodiversity, the vital role of protected areas in conservation has been reemphasized (Swinnerton, 2002). 
The shift to a more protective role was most apparent in developed countries, such as Canada and the US, from which protective legislation influenced national parks around the world. US government policies suggested that if choices had to be made between use and resource protection, decisions would favor conservation (National Park Service, 2000). It is important for park managers to realize the environmental and cultural values connected to park resources and understand the public's desired benefits and expectations, particularly regarding visitors' use of nature (Nilsen \& Taylor, 1999). Managers should consider people's perceptions of protected areas in developing policies and guidelines.

\section{Methods and Study Location}

This study examines how tourists' value orientations can influence their perceptions of the appropriate use of national parks. A questionnaire was used to collect data at Taman Negara National Park (TNNP), Malaysia. TNNP was chosen because it is the oldest official protected area in Malaysia, with one of the world's oldest rainforests-approximately 130 million years old - and is one of the most popular parks in the country. It encompasses varied environments with an extremely rich biodiversity, and popular adventure activities and facilities are provided for visitors. TNNP covers $4,343 \mathrm{~km}^{2}$ and overlaps the state borders of Pahang, Kelantan, and Terengganu (Taman Negara Malaysia, 2012).

An on-site self-administered questionnaire was used based on related instruments from De Groot and Steg (2008), Deng, Walker, and Swinnerton (2005), Dunlap, Van Liere, Mertig, and Jones (2000) and Huang, Deng, Li, and Zhong (2008). This tool was chosen for its two main advantages. First, the researchers were able to collect all completed questionnaires in a relatively short time. Second, if participants had any doubts or needed clarification, these could be addressed on the spot. Section 1 of the survey aimed to identify participants' value orientations. This variable included 13 items of egoistic, altruistic, and biospheric values. The egoistic value orientation addressed the values that benefit oneself. The altruistic value orientation was informed by asking participants to designate to what extent values referring to the well-being of others are important. To understand biospheric value orientation, participants were requested to indicate the degree of importance of ecological values.

The second section determined participants' environmental concern by utilizing 15 items derived from the New Ecological Paradigm (NEP) scale. This scale aims to understand people's proecological orientation. Agreement with eight oddnumbered items and disagreement with seven even-numbered items was anticipated to show proecological worldviews. These items were reversecoded to ensure that high scores represented a proecological perspective.

The third part of the questionnaire related to perceived appropriate uses of national parks. In this section, participants addressed the appropriateness of 37 items concerning accommodations, services, activities, and facilities in national parks. The data were collected during a 3-week period in front of the main entrance to TNNP. Every second entrant was invited to participate in the study. Ultimately, 400 questionnaires were distributed, of which 379 were completed and usable, resulting in a high response rate of $94.75 \%$. International tourists completed 204 surveys and 175 were completed by Malaysian tourists. This sample size is sufficient for a population of less than 1 million (Sekaran \& Bougie, 2010) and is consistent with the number of TNNP visitors.

\section{Data Analysis}

Three tests were applied using the Statistical Package for Social Science (SPSS) version 21.0 to meet the study objectives and to test the hypotheses. Descriptive analysis, factor analysis, and regression analysis were done. The descriptive analysis occurred prior to inferential examinations to identify respondents' perceptions of the appropriate use of parklands (accommodations, services, facilities and activities) through attained mean scores. Confirmatory factor analysis (CFA) and exploratory factor analysis (EFA) are commonly used to lessen and purify items in a scale to form consistent subscales. Moreover, they can be utilized to decrease many associated variables to a more controllable number before exploiting them in further uses, such as multivariate or regression analysis (Pallant, 2011). CFA is generally used to check latent processes, and it is 
often carried out with structural equation modeling (Tabachnick \& Fidell, 2007). EFA was used during the preliminary phase of the research to describe correlations between variables by grouping them. EFA was chosen for uniting variables to generate hypotheses regarding underlying processes.

In addition, a principal components method was utilized as an extraction technique with varimax rotation under an orthogonal rotation approach, which provides easier outcomes in reporting and interpreting results (Pallant, 2011; Tabachnick \& Fidell, 2007).

Several standard multiple regressions were done to identify any connections between egoistic, altruistic, and biospheric values (predictors) and divisions in perceptions of appropriate use of national parks. The intervening effect of environmental concern toward the relationship between tourists' value orientations and their perceptions of appropriate national park use was investigated through a standard multiple regression. Finally, the results from these analyses were verified with the Process: A Versatile Modeling Tool for SPSS (Hayes, 2012) to reconfirm the findings regarding the mediating effect of environmental concern.

\section{Evaluation and Results}

A reliability test checked the internal consistency of scales before the analyses used to address the research objectives and questions (Pallant, 2011). This was important to provide consistency between specified scores in every part of the data. Cronbach's alpha coefficient is one general indicator for internal consistency and was implemented for sections 1 , 2 , and 3 of the questionnaire. Section 1, comprising 13 items, recorded a reliability coefficient value of 0.70 , even as sections 2 and 3, including 15 and 37 items, attained reliability coefficient values of 0.71 and 0.91 , respectively. All Cronbach alpha values were higher than 0.70 , which is an ideal score and suitable for continued analysis (Field, 2009).

The descriptive statistics related to tourists' perceptions of appropriate use of national parkspercentage of responses for each item, the mean, and the standard deviation-are presented in Table 1.

The two highest means were "taking pictures" $(M=4.4, S D=0.86)$ and "hiking/backpacking" $(M=4.3, S D=0.74)$, while the two lowest were "hunting" $(M=1.9, S D=1.19)$ and "golf courses"
$(M=1.9, S D=1.20)$. The highest are appreciative of nature and nonconsumptive; the lowest are consumptive activities, with golf courses requiring significant physical development.

\section{Factor Analysis}

After running a factor analysis on 37 items on the appropriate use scale, 8 factors with an eigenvalue over 1 appeared (Table 2). Factor 1 contained 12 items. Factor 2 included 8 items, followed by factor 3, which included 4 items. Five items fell under factor 4. Factor 5 consisted of 3 items; item 24 "picnicking/barbecuing" cross-loaded with factors 6 and 7. Item 1 "tents/campgrounds" and item 35 "religious activities" did not load with other items and made factors 7 and 8, respectively. Factor 6 included item 23 "non-motorized boating" and item 32 "horse riding". Interpreting factors that contain only one or two items is unreliable; factors with three or more loading items are preferred (Pallant, 2011). As a result, items 1, 23, 24, 32, and 35 and factors 6, 7, and 8 were eliminated from further analysis (Table 2). Subsequently, parallel analysis was run to confirm the number of factors that should be retained, supporting the decision to keep five factors. Five components were accepted because of their greater actual eigenvalues from the principle component analysis (PCA), rather than relevant criterion values from the parallel analysis (PA) in which factor 1 obtained PCA $=9.06$, $\mathrm{PA}=1.65$ and followed by factor 2 (PCA $=4.13$, $\mathrm{PA}=1.56)$, factor 3 (PCA = 2.89, $\mathrm{PA}=1.50)$, factor $4(\mathrm{PCA}=1.92, \mathrm{PA}=1.46)$, and factor $5(\mathrm{PCA}=1.45$, $\mathrm{PA}=1.41)$.

Table 3 displays five exploitable factors and their eigenvalues, percent of variance, and cumulative percent.

Factor analysis regarding the value orientation scale revealed three factors with eigenvalues exceeding 1 (Table 4). Five items - authority, social power, being influential, wealth, and being ambitiousconstituted factor 1 . Preventing pollution, protecting the environment, respecting the earth, and unity with nature formed factor 2. Social justice, being helpful, equality, and a world at peace constituted factor 3 .

Parallel analysis was carried out to confirm the results of the factor analysis. The outcomes of the parallel analysis demonstrated that three emerged 
Table 1

Percent, Means, and Standard Deviations for Appropriate Use of National Parks

\begin{tabular}{|c|c|c|c|c|c|c|c|}
\hline \multirow[b]{2}{*}{ Items } & \multicolumn{5}{|c|}{ Percent of Respondents } & \multicolumn{2}{|c|}{$\begin{array}{c}\text { Descriptive } \\
\text { Statistics }\end{array}$} \\
\hline & $\mathrm{HI}$ & MI & $\mathrm{N}$ & MA & HA & $M$ & $S D$ \\
\hline \multicolumn{8}{|l|}{ Highly appropriate (over 4 points) } \\
\hline 26. Taking pictures & 1.8 & 2.4 & 7.7 & 34.0 & 54.1 & 4.4 & 0.86 \\
\hline 25. Hiking/Backpacking & 0.0 & 1.6 & 11.9 & 40.1 & 46.4 & 4.3 & 0.74 \\
\hline 12. Visitor information/Interpretive centers & 2.4 & 4.2 & 13.8 & 29.3 & 50.3 & 4.2 & 0.99 \\
\hline 20. Jogging/Running/Walking & 0.5 & 2.4 & 13.7 & 50.9 & 32.5 & 4.1 & 0.77 \\
\hline 23. Non-motorized boating/Canoeing/Kayaking/ Rafting & 1.1 & 5.3 & 15.8 & 38.5 & 39.3 & 4.1 & 0.92 \\
\hline 21. Wildlife watching & 0.0 & 1.6 & 14.8 & 56.7 & 26.9 & 4.1 & 0.69 \\
\hline \multicolumn{8}{|l|}{ Moderately appropriate (3-3.99 points) } \\
\hline 8. Hospital/Medical services & 4.5 & 8.4 & 18.5 & 25.6 & 43.0 & 3.9 & 1.16 \\
\hline 34. Rock-climbing/Mountaineering & 5.6 & 5.3 & 21.4 & 34.4 & 33.3 & 3.9 & 1.11 \\
\hline 1. Tents/campgrounds & 2.1 & 5.6 & 22.4 & 45.9 & 24.0 & 3.8 & 0.92 \\
\hline 13. School/Educational services & 6.6 & 7.4 & 18.5 & 31.1 & 36.4 & 3.8 & 1.19 \\
\hline 30. Caving & 4.7 & 5.5 & 25.9 & 39.6 & 24.3 & 3.7 & 1.04 \\
\hline 31. Swimming/Sunbathing & 5.5 & 7.9 & 26.4 & 30.6 & 29.6 & 3.7 & 1.14 \\
\hline 2. Hotel/motel accommodation & 4.7 & 13.5 & 29.6 & 34.0 & 18.2 & 3.4 & 1.08 \\
\hline 18. Mountain biking & 6.3 & 14.8 & 26.1 & 33.5 & 19.3 & 3.4 & 1.14 \\
\hline 9. Restaurants or lounges & 7.7 & 15.5 & 30.1 & 23.5 & 23.2 & 3.4 & 1.21 \\
\hline 24. Picnicking/Barbecuing & 15.3 & 14.3 & 18.7 & 30.1 & 21.6 & 3.3 & 1.36 \\
\hline 28. Fishing & 11.3 & 12.2 & 34.3 & 28.0 & 14.2 & 3.2 & 1.17 \\
\hline $\begin{array}{l}\text { 27. Gathering natural edible products (fruit, berries, mushrooms, } \\
\text { fern fiddleheads, etc) }\end{array}$ & 17.5 & 11.6 & 25.7 & 27.5 & 17.7 & 3.2 & 1.33 \\
\hline 14. Grocery stores & 12.1 & 17.7 & 27.7 & 27.7 & 14.8 & 3.2 & 1.23 \\
\hline 4. Children's playgrounds & 15.6 & 15.5 & 25.6 & 27.2 & 16.1 & 3.1 & 1.30 \\
\hline \multicolumn{8}{|l|}{ Moderately inappropriate (2-2.99 points) } \\
\hline 11. Gift shops & 14.6 & 22.4 & 32.3 & 16.4 & 14.3 & 2.9 & 1.24 \\
\hline 35. Religious activities & 21.1 & 12.4 & 36.4 & 14.0 & 16.1 & 2.9 & 1.32 \\
\hline 32. Horse riding & 20.1 & 18.8 & 26.7 & 26.7 & 7.7 & 2.8 & 1.24 \\
\hline 16. Pavilions & 16.7 & 24.0 & 30.7 & 17.5 & 11.1 & 2.8 & 1.22 \\
\hline 10. Gas/Service stations & 23.5 & 22.5 & 20.1 & 20.7 & 13.2 & 2.8 & 1.36 \\
\hline 15. Conference facilities & 21.9 & 20.1 & 29.0 & 16.9 & 12.1 & 2.8 & 1.30 \\
\hline 5. Sport fields (soccer, basketball, etc.) & 26.4 & 17.7 & 25.9 & 17.9 & 12.1 & 2.7 & 1.35 \\
\hline 19. Small aircraft flights & 27.7 & 25.1 & 25.8 & 14.5 & 6.9 & 2.5 & 1.23 \\
\hline 37. Power boating & 35.9 & 22.7 & 16.4 & 16.6 & 8.4 & 2.4 & 1.34 \\
\hline 29. Chair lifts/Cable cars/Sightseeing elevators & 31.9 & 26.6 & 22.7 & 13.5 & 5.3 & 2.3 & 1.20 \\
\hline 36. Sightseeing by car & 35.1 & 28.2 & 21.6 & 11.9 & 3.2 & 2.2 & 1.14 \\
\hline 17. Shopping centers & 49.1 & 16.9 & 19.5 & 8.2 & 6.3 & 2.1 & 1.26 \\
\hline 7. Skiing area & 49.7 & 19.9 & 12.4 & 11.7 & 6.3 & 2.1 & 1.29 \\
\hline 3. Residency/permanent homes & 49.1 & 19.0 & 18.5 & 7.1 & 6.3 & 2.0 & 1.24 \\
\hline 22. Dancing/karaoke lounges & 49.7 & 19.1 & 17.2 & 8.7 & 5.3 & 2.0 & 1.22 \\
\hline \multicolumn{8}{|l|}{ Highly inappropriate (below 1.99 points) } \\
\hline 33. Hunting & 55.0 & 18.3 & 14.0 & 7.9 & 4.8 & 1.9 & 1.19 \\
\hline 6. Golf courses & 55.8 & 19.9 & 13.2 & 4.8 & 6.3 & 1.9 & 1.20 \\
\hline
\end{tabular}

eigenvalues from the principle component analysis are greater than the parallel analysis' criterion values for factor 1 (PCA = 3.02, PA = 1.32), factor 2 $(\mathrm{PCA}=2.29, \mathrm{PA}=1.24)$, and factor 3 (PCA $=1.18$, $\mathrm{PA}=1.17)$. The extraction of three factors to measure value orientation was verified by parallel analysis.

Factor 1 comprises five items that reveal tourists' egoistic value orientation and attained an eigenvalue of 3.02 and percent of variance of $23.3 \%$. Factor 2 includes four items that show tourists' biospheric value orientation with 2.29 and $17.6 \%$ of eigenvalue and percent of variance, respectively. Factor 3 consists of four items that exhibit tourists' altruistic value orientation and presented 1.18 eigenvalue and $9.1 \%$ of variance. Cumulatively, these three factors explain $50 \%$ of the variance. 
Table 2

Principle Component Analysis of Appropriate Use of National Parks Using Varimax Rotation

\begin{tabular}{|c|c|c|c|c|c|}
\hline \multirow[b]{2}{*}{ Items } & \multicolumn{5}{|c|}{ Factors } \\
\hline & 1 & 2 & 3 & 4 & 5 \\
\hline \multicolumn{6}{|l|}{ 1. Tents/campgrounds ${ }^{\mathrm{a}}$} \\
\hline 2. Hotel/motel accommodation & 0.64 & -0.07 & -0.05 & 0.24 & 0.05 \\
\hline 3. Residency/permanent homes & 0.54 & -0.01 & 0.39 & 0.31 & 0.22 \\
\hline 4. Children’s playgrounds & 0.25 & 0.05 & -0.11 & 0.75 & 0.15 \\
\hline 5. Sport fields (soccer, basketball, etc.) & 0.30 & -0.02 & 0.06 & 0.76 & 0.10 \\
\hline 6. Golf courses & 0.17 & -0.05 & 0.33 & 0.70 & 0.13 \\
\hline 7. Skiing area & 0.07 & 0.13 & 0.30 & 0.63 & 0.14 \\
\hline 8. Hospital/medical services & 0.67 & -0.04 & -0.16 & 0.16 & 0.14 \\
\hline 9. Restaurants or lounges & 0.77 & 0.10 & 0.14 & 0.08 & 0.11 \\
\hline 10. Gas/service stations & 0.72 & 0.10 & 0.28 & 0.06 & 0.03 \\
\hline 11. Gift shops & 0.74 & 0.25 & 0.19 & 0.09 & 0.09 \\
\hline 12. Visitor information/interpretive centers & 0.53 & 0.07 & -0.13 & -0.22 & -0.18 \\
\hline 13. School/educational services & 0.53 & 0.09 & 0.06 & 0.14 & -0.01 \\
\hline 14. Grocery stores & 0.77 & 0.15 & 0.29 & 0.11 & 0.03 \\
\hline 15. Conference facilities & 0.59 & 0.17 & 0.36 & 0.25 & -0.09 \\
\hline 16. Pavilions & 0.61 & 0.23 & 0.35 & 0.11 & -0.09 \\
\hline 17. Shopping centers & 0.55 & -0.02 & 0.38 & 0.32 & 0.23 \\
\hline 18. Mountain biking & 0.02 & 0.41 & 0.29 & 0.21 & 0.08 \\
\hline 19. Small aircraft flights & 0.27 & 0.09 & 0.53 & 0.30 & -0.02 \\
\hline 20. Jogging/running/walking & 0.09 & 0.80 & 0.02 & 0.03 & 0.04 \\
\hline 21. Wildlife watching & 0.06 & 0.85 & -0.06 & 0.04 & 0.02 \\
\hline 22. Dancing/karaoke lounges & 0.13 & -0.16 & 0.24 & 0.66 & 0.00 \\
\hline \multicolumn{6}{|l|}{ 23. Nonmotorized boating/canoeing/kayaking/rafting ${ }^{\mathrm{a}}$} \\
\hline \multicolumn{6}{|l|}{ 24. Picnicking/barbecuing ${ }^{\mathrm{a}}$} \\
\hline 25. Hiking/Backpacking & 0.15 & 0.89 & -0.07 & -0.03 & 0.03 \\
\hline 26. Taking pictures & 0.12 & 0.44 & -0.05 & -0.32 & 0.10 \\
\hline $\begin{array}{l}\text { 27. Gathering natural edible products (fruit, berries, mushrooms, fern } \\
\text { fiddleheads, etc) }\end{array}$ & 0.16 & 0.04 & 0.14 & 0.09 & 0.70 \\
\hline 28. Fishing & 0.09 & 0.23 & 0.03 & 0.15 & 0.76 \\
\hline 29. Chair lifts/cable cars/sightseeing elevators & 0.16 & 0.05 & 0.66 & 0.12 & 0.13 \\
\hline 30. Caving & 0.21 & 0.48 & 0.19 & -0.19 & 0.27 \\
\hline 31. Swimming/sunbathing & 0.16 & 0.49 & 0.19 & -0.16 & 0.08 \\
\hline \multicolumn{6}{|l|}{ 32. Horse riding ${ }^{\mathrm{a}}$} \\
\hline 33. Hunting & -0.16 & -0.04 & 0.39 & 0.20 & 0.52 \\
\hline 34. Rock-climbing/mountaineering & 0.04 & 0.60 & 0.27 & 0.07 & 0.00 \\
\hline \multicolumn{6}{|l|}{ 35. Religious activities ${ }^{\mathrm{a}}$} \\
\hline 36. Sightseeing by car & 0.10 & -0.03 & 0.73 & 0.21 & 0.21 \\
\hline 37. Power boating & 0.30 & 0.06 & 0.74 & 0.03 & 0.03 \\
\hline
\end{tabular}

atem eliminated.

Table 3

Factor Extraction for Appropriate Use of National Parks $(N=379)$

\begin{tabular}{lcccc}
\hline Factors & Items & Eigenvalue & Percent of Variance & Cumulative Percent \\
\hline 1. Accommodation and service facilities & 12 & 9.05 & 24.5 & 24.5 \\
2. Nonconsumptive activities & 8 & 4.13 & 11.1 & 35.6 \\
3. Motorized activities & 4 & 2.89 & 7.8 & 43.4 \\
4. Sport/recreation facilities & 5 & 1.92 & 5.2 & 48.6 \\
5. Consumptive activities & 3 & 1.45 & 3.9 & 52.5 \\
\hline
\end{tabular}


Table 4

Principle Component Analysis from Value Orientations Using Varimax Rotation

\begin{tabular}{lrrr}
\hline & \multicolumn{3}{c}{ Factors } \\
\cline { 2 - 4 } Items & \multicolumn{1}{c}{ - } & 2 & 3 \\
\hline 8. Authority: the right to lead or command & 0.76 & 0.26 & -0.12 \\
3. Social power: control over others, dominance & 0.70 & -0.01 & -0.21 \\
10. Being influential: having an impact on people and events & 0.69 & 0.03 & 0.16 \\
6. Wealth: material possessions, money & 0.63 & -0.14 & 0.11 \\
12. Being ambitious: hard-working, aspiring & 0.55 & 0.16 & 0.38 \\
13. Preventing pollution: protecting natural resources & 0.12 & 0.79 & 0.22 \\
9. Protecting the environment: preserving nature & 0.04 & 0.76 & 0.27 \\
2. Respecting the earth: harmony with other species & -0.07 & 0.72 & 0.27 \\
4. Unity with nature: fitting into nature & 0.04 & 0.59 & -0.17 \\
7. Social justice: correcting injustice, care for the weak & -0.01 & 0.26 & 0.66 \\
11. Being helpful: working for the welfare of others & 0.08 & 0.17 & 0.59 \\
1. Equality: equal opportunity for all & -0.33 & 0.14 & 0.55 \\
5. A world at peace: free of war and conflict & 0.15 & -0.08 & 0.47 \\
\hline
\end{tabular}

\section{Hypotheses Testing}

To check the first hypothesis, five multiple regression tests were conducted to consider the relationship between variables (Table 5). Before conducting multiple regression tests, preliminary tests were performed to ensure assumptions of normality, multicollinearity, homoscedasticity, and linearity were not violated.

\section{H1a: There Is a Significant Relationship Between} Value Orientations and Accommodation and Service Facilities. A standard multiple regression tested the relationship between three value orientations-egoistic value orientation, altruistic value orientation, biospheric value orientation-as predictors, and accommodation and service facilities as a dependent variable (Table 5).

The outcomes of the multiple regression showed that the model was significant $\left[R^{2}=0.25\right.$, adj. $\left.R^{2}=0.24, F(3,375)=41.84, p<0.001\right]$. Coefficient of determination, the so-called $R^{2}$, determines that $25 \%$ of the variance in suitability of accommodation and service facilities in national parks can be explained by value orientations.

H1b: There Is a Significant Relationship Between Value Orientations and Nonconsumptive Activities. The next multiple regression analysis was conducted to scrutinize the relationship between three value orientations, egoistic values, altruistic values, and biospheric values, as three explanatory variables, and nonconsumptive activities in national parks as a criterion variable (Table 5).

According to the table, value orientations demonstrate $6 \%$ of variation as the predictor variable toward nonconsumptive activities as the outcome variable $\left(R^{2}=0.06\right)$. The result revealed a relationship between value orientations and nonconsumptive activities in national parks $\left[R^{2}=0.06\right.$, adj. $\left.R^{2}=0.05, F(3,375)=7.61, p<0.001\right]$.

H1c: There Is a Significant Relationship Between Value Orientations and Motorized Activities. Another multiple regression test examined the relationships between egoistic value orientation, altruistic value orientation, and biospheric value orientation as three explanatory variables and motorized activities as a dependent variable. The results disclosed statistical significance $\left[R^{2}=0.17\right.$, adj. $R^{2}=0.16, F(3$, $375)=25.13, p<0.001$ ] (Table 5). Seventeen percent of variance in the dependent variable (motorized activities) can be predicted by the independent variables (predictor variables).

H1d: There Is a Significant Relationship Between Value Orientations and Sport/Recreation Facilities. The next multiple regression analysis pertained to the relationship between egoistic, altruistic, and biospheric value orientations variables and a criterion variable (sport/recreation facilities) (Table 5). Based on the results, the model was significant $\left[R^{2}=0.07\right.$, 
Table 5

Multiple Regression Statistics for Value Orientations and Criterion Variables

\begin{tabular}{|c|c|c|c|c|}
\hline Criterion Variables/Predictor Variables & B & SE B & $\beta$ & $R^{2}$ \\
\hline Accommodation and service facilities & & & & 0.25 \\
\hline Constant & 18.59 & 5.08 & & \\
\hline Egoistic value orientation & 0.98 & 0.09 & $0.47 * * *$ & \\
\hline Altruistic value orientation & -0.59 & 0.18 & $-0.16 * *$ & \\
\hline Biospheric value orientation & 0.37 & 0.20 & 0.09 & \\
\hline Nonconsumptive activities & & & & 0.06 \\
\hline Constant & 19.86 & 2.69 & & \\
\hline Egoistic value orientation & 0.04 & 0.05 & 0.04 & \\
\hline Altruistic value orientation & 0.01 & 0.10 & 0.01 & \\
\hline Biospheric value orientation & 0.41 & 0.11 & $0.22 * * *$ & \\
\hline Motorized activities & & & & 0.17 \\
\hline Constant & 8.91 & 2.00 & & \\
\hline Egoistic value orientation & 0.29 & 0.04 & $0.37 * * *$ & \\
\hline Altruistic value orientation & -0.26 & 0.07 & $-0.19 * * *$ & \\
\hline Biospheric value orientation & -0.01 & 0.08 & -0.01 & \\
\hline Sport/recreation facilities & & & & 0.07 \\
\hline Constant & 13.20 & 2.75 & & \\
\hline Egoistic value orientation & 0.24 & 0.05 & $0.24^{* * *}$ & \\
\hline Altruistic value orientation & -0.17 & 0.10 & -0.09 & \\
\hline Biospheric value orientation & -0.13 & 0.11 & -0.07 & \\
\hline Consumptive activities & & & & 0.06 \\
\hline Constant & 10.23 & 1.56 & & \\
\hline Egoistic value orientation & 0.12 & 0.03 & $0.21 * * *$ & \\
\hline Altruistic value orientation & -0.06 & 0.06 & -0.06 & \\
\hline Biospheric value orientation & -0.13 & 0.06 & $-0.12 *$ & \\
\hline
\end{tabular}

adj. $\left.R^{2}=0.06, F(3,375)=9.13, p<0.001\right]$, with the predictors explaining $7 \%$ of the variation in sport/recreation facilities.

\section{H1e: There Is a Significant Relationship Between} Value Orientations and Consumptive Activities. Another multiple regression was implemented to understand the relationship between consumptive activities in national parks (outcome variable) and the tripartite classification of value orientations (Table $5)$. The results of the simple multiple regression indicate that the model was significant $\left[R^{2}=0.06\right.$, adj. $\left.R^{2}=0.05, F(3,375)=7.89, p<0.001\right]$. On the basis of $\left(R^{2}\right)$ reputed coefficient of determination, $6 \%$ of the variance in consumptive activities as a dependent variable is explained by the aforementioned three independent variables.

H2: Environmental Concern Mediates the Relationship Between Value Orientations and Appropriate Use of National Parks. The second hypothesis of the study identified the mediating effect of environmental concern on the relationship between value orientations and appropriate use of national parks. With that purpose, three regression analyses were conducted and the outcomes are condensed in Table 6.

In step 1 and 2, value orientations were significantly correlated with appropriate use of national parks and environmental concern, respectively. In step 3, environmental concern, which is the mediating variable, was significantly correlated with appropriate use of national parks. Moreover, value orientations also had a significant effect on the appropriate use of national parks, while controlling for environmental concern.

\section{Discussion}

The first objective of this study was to understand tourists' perceptions of appropriate uses of, and services in, national parks. Based on the mean scores, 37 items concerning accommodations, facilities, and activities within national parks were classified into four categories. Items with mean 
Table 6

Regression Analyses on Environmental Concern Mediating the Relationship Between Value Orientations and Appropriate Use of National Parks

\begin{tabular}{lcccc}
\hline Steps and Variables & B & SE B & $95 \%$ CI & $\beta$ \\
\hline $\begin{array}{l}\text { Testing Step 1 (path c) } \\
\quad \text { Outcome: Appropriate use of national parks }\end{array}$ & & & & \\
$\quad$ Predictor: Value orientations & 1.68 & 0.18 & $1.33,2.04$ & $0.43^{* * *}$ \\
$\quad \begin{array}{l}\text { Testing Step 2 (path a) } \\
\quad \text { Outcome: Environmental concern }\end{array}$ & -0.72 & 0.05 & $-0.82,-0.61$ & $-0.58^{* * *}$ \\
$\quad \begin{array}{l}\text { Predictor: Value orientations } \\
\text { Testing Step 3 (path b and c') }\end{array} \quad$ & & & \\
$\quad$ Outcome: Appropriate use of national parks & & & & \\
$\quad$ Mediator: Environmental concern (path b) & -0.84 & 0.17 & $-1.19,-0.50$ & $-0.27^{* * *}$ \\
$\quad$ Predictor: Value orientations (path c') & 1.08 & 0.21 & $0.65,1.50$ & $0.28^{* * *}$ \\
\hline
\end{tabular}

Note. $\mathrm{CI}=$ confidence interval.

$* * * p<0.001$.

scores less than 2 are considered highly inappropriate, between 2 and 2.99 moderately inappropriate, 3 and above but less than 4 moderately appropriate, and greater than 4 highly appropriate. Only 2 items were highly inappropriate and 15 items were moderately inappropriate. In the moderately appropriate category were 14 items; 6 items were considered highly appropriate. The level of appropriateness of each activity derives from people's values and environmental appreciation.

Golf courses were the least appropriate use. Perhaps this reflects one of the main environmental challenges in Asia: the rapid development of golf courses (Nair, 2008). Developers are frequently deceptive about the environmentally friendly nature of their proposed development and the number of jobs that will materialize (Omar, Othman, \& Mohamed, 2014). Many residents end up being low-paid laborers. Their economic self-reliance changes drastically when they lose their farms and have to find working at these golf courses. This tends to disintegrate rural communities and force many rural people to the urban fridge.

Some items in this study related to accommodation and services, motorized activities, and sport/ recreation facilities were considered moderately inappropriate uses. This contrasts with Huang et al.'s (2008) study, which found that horse riding, small airplane flights, skiing, and pavilions were moderately appropriate activities in one Chinese protected area.

From participants' perspective, moderately appropriate uses were associated with tents/campgrounds, hospital/medical services, restaurants or lounges, consumptive activities, nonconsumptive activities, and sport/recreation facilities. Interestingly, tourists perceived fishing and foraging for edible products as moderately appropriate uses of national parks, even though both of these activities are consumptive. These findings correspond with other studies (Anderson, Blahna, \& Chavez, 2000; Huang et al., 2008), which concluded that foragers perceive their activities to be unthreatening to the environment.

Study participants regarded appreciative activities to be highly appropriate. These activities are nonconsumptive and are perceived to have few, if any, negative impacts, compared to motorized activities or consumptive uses. These results confirm the findings of previous studies (Deng et al., 2005; Huang et al., 2008).

\section{Value Orientations and Appropriate Use of National Parks}

Five sets of standard multiple regression tests were conducted to understand the relationship between tourists' value orientations and their perceptions of appropriate use. The results indicated among the three predictors entered into the model, only egoistic $(\beta=0.47, p<0.001)$ and altruistic $(\beta=-0.16$, $p<0.01)$ value orientations were statistically significant for accommodation and service facilities.

Biospheric value orientation was the only explanatory variable that made a statistically significant and positive contribution in explaining nonconsumptive activities $(\beta=0.22, p<0.001)$. 
In the relationship between value orientations and motorized activities, only egoistic value orientation $(\beta=0.37, p<0.001)$ and altruistic value orientation $(\beta=-0.19, p<0.001)$ made statistically significant contributions to perceived appropriateness.

Other findings suggest, out of the three predictors, only egoistic value orientation was statistically significant related to tourists' perceptions of the appropriateness of sport/recreation facilities within national parks $(\beta=0.24, p<0.001)$. In addition, two value orientations of egoistic $(\beta=0.21$, $p<0.001)$ and biospheric $(\beta=-0.12, p<0.05)$ were statistically associated with appropriateness of consumptive activities.

\section{Environmental Concern, Value Orientations, and Appropriate Use of National Parks}

Three regression analyses were performed to scrutinize direct effect (path c), indirect effect (path c'), path (a) and (b) based on the Barron and Kenny method (Frazier, Tix, \& Barron, 2004; Kenny, 2013) (Table 6). The results indicate that environmental concern partially mediates the association between value orientations and appropriate use of national parks inasmuch as all four paths comprising path (c), path (a), path (b) and path (c') were statistically significant. To confirm the significant drop between paths (c) and ( $\left.\mathrm{c}^{\prime}\right)$, a Sobel test was performed. The result indicated a significant $\mathrm{p}$ value $(p<0.001)$, and the amount of indirect effect was 35.9\%. Approximately one third of the effect of value orientations on the appropriateness of activities, facilities, and services in national parks relates to environmental concern (mediating variable) and about two thirds of the effect is direct (64.1\%). As the indirect effect was less than $50 \%$, the Sobel test also supported that environmental concern (mediator) partially mediates the relationship between value orientations and perceptions toward national parks appropriate uses. Using the Hayes Process Method (Hayes, 2012) to determine the mediating or moderating effect, the point estimates of confidence intervals were positive (LLCI $=0.35$, ULCI $=0.87$ ), and consequently, none fell between them at a 95\% confidence level. Accordingly, the idea that environmental concern significantly mediates the relationship between value orientations and appropriate use of national parks was corroborated.
This results agree with previous findings by Nordlund and Garvill (2002, 2003) and Poortinga, Steg, and Vlek (2004), who established that generally some factors such as personal norms and specific beliefs mediate the association between values and behaviors due to the lack of strong direct effect of values on behaviors in general. In addition, the results are consistent with the findings of Steg et al. (2005) and De Groot and Steg (2009), which state that values are strong in anticipating proenvironmental intentions, and predilections and interventions in a certain situation could enfeeble the effect of egoistic values or strengthen the influence of altruistic and biospheric values.

\section{Conclusion}

Individuals have unique life experiences that differentiate them from other people. These experiences determine perceptions of authenticity, reality, beliefs, environmental values, senses of right and wrong, and many other subjective norms that affect their everyday lives, including their travel expectations, interests, and desires. As noted at the outset of this article, these personal norms affect individuals' worldviews and determine their behaviors (Johansson et al., 2013), leading them either to reject what is incongruous to their beliefs or accept what is congruous (Hansla, 2011). One set of personal beliefs common in the tourism and conservation literature today is environmental consciousness. Within its geographic limitations, this study shows that people whose value orientations are closely aligned with environmental consciousness demonstrate considerable concern about how protected areas are used by visitors and serviced by park management. As well, people with differing value orientations will also differ in their perceptions of appropriateness of national park uses and services. People's environmental appreciation values will determine their reactions to consumptive and nonconsumptive activities, as well as the services and facilities provided in natural protected areas. Therefore, understanding visitors' values and attitudes is vital in minimizing the negative impacts of tourism in parklands.

This research contribution is to evaluate the relationship between three sorts of value orientations as independent variables and five types of appropriate 
use of national parks. The findings also suggest that environmental concern partially mediates the relationship between value orientations and people's perceptions of appropriate park activities.

According to this study, visitors perceive appreciative or passive activities to be the most appropriate pursuits within national parks. It can be concluded that visitors with lower levels of egoistic values and higher levels of altruistic values see accommodation, service facilities, and motorized activities as less compatible with the aims of protected areas. Predictably, higher levels of biospheric values and lower levels of egoistic values render consumptive activities less appropriate. Park visitors with a higher degree of biospheric value orientation perceive nonconsumptive activities to be more appropriate within national parks.

One of the limitations of this study is that it took place in a particular national park, and it is therefore difficult to establish implications for other protected areas. Still, the findings have salient implications. Park management can see a clearer picture of what influences park visitors' perceptions of appropriate uses and activities. The results are helpful for planning, developing, and managing accommodations, facilities, and services. In line with De Groot and Steg (2010), this study infers that policies can foster tourists' proenvironmental priorities by reinforcing their values, specifically their altruistic and biospheric ideals. While changing people's values is difficult, it is possible to encourage individuals to act more in line with altruistic and biospheric values.

\section{References}

Ajzen, I. (1991). The theory of planned behavior. Organizational Behavior and Human Decision Processes, 50, 179-211.

Alazaizeh, M. M., Hallo, J. C., Backman, S. J., Norman, W. C., \& Vogel, M. A. (2016). Value orientations and heritage tourism management at Petra Archaeological Park, Jordan. Tourism Management, 57, 149-158.

Alipour, H., Olya, H. G., \& Forouzan, I. (2017). Environmental impacts of mass religious tourism: From residents' perspectives. Tourism Analysis, 22(2), 167-183.

Anderson, J. A., Blahna, D. J., \& Chavez, D. J. (2000). Fern gathering on the San Bernardino National Forest: Cultural versus commercial values among Korean and Japanese participants. Society and Natural Resources, 13, 747-762.

Bajs, I. P. (2015). Tourist perceived value, relationship to satisfaction, and behavioral intentions: The example of the Croatian tourist destination Dubrovnik. Journal of Travel Research, 54(1), 122-134.

Bimonte, S., \& Faralla, V. (2015). Happiness and outdoor vacations: Appreciative versus consumptive tourists. Journal of Travel Research, 54(2), 179-192.

Borrie, W. T., Freimund, W. A., \& Davenport, M. A. (2002). Winter visitors to Yellowstone National Park: Their value orientations and support for management actions. Human Ecology Review, 9(2), 41-48.

Clark, T. W., Willard, A. R., \& Cromley, C. M. (Eds.). (2000). Foundations of natural resources policy and management. New Haven, CT: Yale University Press.

Clement, J. M., \& Cheng, A. S. (2011). Using analyses of public value orientations, attitudes and preferences to inform national forest planning in Colorado and Wyoming. Applied Geography, 31(2), 393-400.

Crespo, N., Simões, N., \& Duarte, J. (2016). Competition in tourism arrivals: A multidimensional index of geographical structural similarity. Tourism Analysis, 21(1), 29-45.

De Groot, J., \& Steg, L. (2008). Value orientations to explain beliefs related to environmental significant behavior: How to measure egoistic, altruistic, and biospheric value orientations. Environment and Behavior, 40(3), 330-354.

De Groot, J., \& Steg, L. (2009). Mean or green? Values, morality and environmental significant behavior. Conservation Letters, 2, 61-66.

De Groot, J., \& Steg, L. (2010). Relationships between value orientations, self-determined motivational types and pro-environmental behavioural intentions. Journal of Environmental Psychology, 30, 368-378.

Deng, J., Walker, G. J., \& Swinnerton, G. (2005). A comparison of attitudes toward national park appropriate use between Chinese in Canada and Anglo-Canadians. World Leisure Journal, 47(3), 28-41.

Drumm, A., \& Moore, A. (2002). Ecotourism development: A manual for conservation planners and managers (Vol. 1). Arlington, VA: The Nature Conservancy.

Dunlap, R. E., Grieneeks, J. K., \& Rokeach, M. (1983). Human values and pro-environmental behavior. In W. D. Conn (Ed.), Energy and material resources: Attitudes, values, and public policy (pp. 145-168). Boulder, CO: Westview.

Dunlap, R. E., Van Liere, K. D., Mertig, A. G., \& Jones, R. E. (2000). Measuring endorsement of the new ecological paradigm: A revised NEP. Journal of Social Issues, 56(3), $425-442$.

Field, A. (2009). Discovering statistics using SPSS (3rd ed.). Thousand Oaks, CA: SAGE.

Fransson, N., \& Garling, T. (1999). Environmental concern: Conceptual definitions, measurement methods, and research findings. Journal of Environmental Psychology, 19, 369-382.

Frazier, P. A., Tix, A. P., \& Barron, K. E. (2004). Testing moderator and mediator effects in counseling psychology research. Journal of Counseling Psychology, 51(1), 115-134.

Frost, W., \& Hall, C. M. (2009). Tourism and national parks: International perspectives on development, histories and change. London, UK: Routledge. 
Gärling, T., Fujii, S., Gärling, A., \& Jakobsson, C. (2003). Moderating effects of social value orientation on determinants of proenvironmental behavior intention. Journal of Environmental Psychology, 23, 1-9.

Ghazvini, S. A. M., Lim, L. K., \& Sarmento, J. (2016). How important are value orientations to environmental concern? A comparison of national and international tourists in Malaysia. African and Asian Studies, 15(2-3), 265-288.

Hansla, A. (2011). Value orientation, awareness of consequences, and environmental concern (doctoral dissertation). University of Gothenburg, Sweden.

Hassell, S., Moore, S. A., \& Macbeth, J. (2015). Exploring the motivations, experiences and meanings of camping in national parks. Leisure Sciences, 37(3), 269-287.

Haukeland, J. V., Daugstad, K., \& Vistad, O. I. (2011). Harmony or conflict? A focus group study on traditional use and tourism development in and around Rondane and Jotunheimen National Parks in Norway. Scandinavian Journal of Hospitality and Tourism, 11(S1), 13-37.

Hayes, A. F. (2012). PROCESS: A versatile computational tool for observed variable mediation, moderation, and conditional process modeling [White paper]. Retrieved from http://www.afhayes.com/public/process2012.pdf

Huang, Y., Deng, J., Li, J., \& Zhong, Y. (2008). Visitors’ attitudes towards China's National Forest Park policy, roles and functions, and appropriate use. Journal of Sustainable Tourism, 16(1), 63-84.

Imran, S., Alam, K., \& Beaumont, N. (2014). Environmental orientations and environmental behaviour: Perceptions of protected area tourism stakeholders. Tourism Management, 40, 290-299.

Jaini, N., Anuar, A. N. A., \& Daim, M. S. (2012). The practice of sustainable tourism in ecotourism sites among ecotourism providers. Asian Social Science, 8(4), 175-179.

Johansson, M., Rahm, J., \& Gyllin, M. (2013). Landowners' participation in biodiversity conservation examined through the value-belief-norm theory. Landscape Research, 38(3), 295-311.

Kenny, D. A. (2013). MEDIATION. Retrieved from http:// davidakenny.net/cm/mediate.htm

Lee, E.-Y., Yi, K. J., Walker, G. J., \& Spence, J. C. (2017). Preferred leisure type, value orientations, and psychological well-being among East Asian youth. Leisure Sciences, 39(4), 355-375.

López-Mosquera, N., \& Sánchez, M. (2012). Theory of planned behavior and the value-belief-norm theory explaining willingness to pay for a suburban park. Journal of Environmental Management, 113, 251-262.

Nair, V. (2008). Golf course development is now emerging as a major environmental issue in Asia. ECOCLUB (International Ecotourism Magazine ${ }^{\mathrm{TM}}$ ). Retrieved from http://ecoclub.com/news/098/interview2.html

Nair, V., \& Azmi, R. (2008). Perception of tourists on the responsible tourism concept in Langkawi, Malaysia: Are we up to it? TEAM Journal of Hospitality \& Tourism, 5(1), 27-44.

National Park Service. (2000). Management policies 2001. Washington, DC: U.S. Department of the Interior.
Nilsen, P., \& Taylor, G. (1999). Parks Canada's handbook: Spectrum of appropriate national park opportunities. Ottawa, Canada: Parks Canada.

Nordlund, A. M., \& Garvill, J. (2002). Value structures behind proenvironmental behavior. Environment and Behavior, 34, 740-756.

Nordlund, A. M., \& Garvill, J. (2003). Effects of values, problem awareness, and personal norm on willingness to reduce personal car use. Journal of Environmental Psychology, 23, 339-347.

Omar, S. I., Othman, A. G., \& Mohamed, B. (2014). The tourism life cycle: An overview of Langkawi Island, Malaysia. International Journal of Culture, Tourism and Hospitality Research, 8(3), 272-289.

Oreg, S., \& Katz-Gerro, T. (2006). Predicting proenvironmental behavior cross-nationally: Values, the theory of planned behavior, and value-belief-norm theory. Environment and Behavior, 38(4), 462-483.

Pallant, J. (2011). SPSS survival manual: A step by step guide to data analysis using SPSS (4th ed.). Crows Nest, Australia: Allen \& Unwin.

Perkins, H., \& Brown, P. (2012). Environmental values and the so-called true ecotourist. Journal of Travel Research, 51(6), 793-803.

Poortinga, W., Steg, L., \& Vlek, C. (2004). Values, environmental concern, and environmental behavior: A study into household energy use. Environment and Behavior, 36(1), 70-93.

Ramkissoon, H., \& Mavondo, F. T. (2017). Proenvironmental behavior: Critical link between satisfaction and place attachment in Australia and Canada. Tourism Analysis, 22(1), 59-73.

Rossi, S. D., Byrne, J. A., Pickering, C. M., \& Reser, J. (2015). 'Seeing red' in national parks: How visitors' values affect perceptions and park experiences. Geoforum, $66,41-52$.

Schwartz, S. (1977). Normative influences on altruism. Advances in Experimental Social Psychology, 10, 221-279.

Sekaran, U., \& Bougie, R. (2010). Research methods for business: A skill-building approach (5th ed.). West Sussex, UK: Wiley.

Steg, L., Dreijerink, L., \& Abrahamse, W. (2005). Factors influencing the acceptability of energy policies: A test of VBN theory. Journal of Environmental Psychology, 25, 415-425.

Stern, P. C. (2000). Toward a coherent theory of environmentally significant behavior. Journal of Social Issues, 56(3), 407-424.

Stern, P. C., Dietz, T., Abel, T., Guagnano, G. A., \& Kalof, L. (1999). A value-belief-norm theory of support for social movements: The case of environmentalism. Human Ecology Review, 6(2), 81-97.

Suttikun, C., Chang, H. J., Komolsevin, R., \& Chongsithiphol, S. (2015). An investigation of environmental and situational factors affecting tourists' behavioral intention to choose Bangkok as their final destination. Tourism Analysis, 20(5), 523-537. 
Swinnerton, G. S. (1999). Recreation and conservation: Issues and prospects. In E. L. Jackson \& T. L. Burton (Eds.), Leisure studies: Prospects for the twenty-first century (pp. 197-229). State College, PA: Venture.

Swinnerton, G. S. (2002). Case study: Banff and the Bow Valley. In P. Dearden \& R. Rollins (Eds.), Parks and protected areas in Canada: Planning and management (2nd ed., pp. 240-264). Don Mills, ON: Oxford University Press.

Tabachnick, B. G., \& Fidell, L. S. (2007). Using multivariate statistics (5th ed.). London, UK: Pearson.

Taman Negara Malaysia. (2012). Peninsular Malaysia. Kuala Lumpur: Department of Wildlife Protection and National Parks.
Taplin, R. H., Rodger, K., \& Moore, S. A. (2016). A method for testing the effect of management interventions on the satisfaction and loyalty of national park visitors. Leisure Sciences, 38(2), 140-160.

Thøgersen, J., \& Ölander, F. (2002). Human values and the emergence of a sustainable consumption pattern: A panel study. Journal of Economic Psychology, 23, 605-630.

Uyeki, E. S., \& Holland, L. J. (2000). Diffusion of proenvironment attitudes? American Behavioral Scientist, 43, 646-662.

Wilkinson, P. F. (2003). Ecological integrity, visitor use, and marketing of Canada's national parks. Journal of Park and Recreation Administration, 21, 63-83. 
Copyright of Tourism Analysis is the property of Cognizant, LLC and its content may not be copied or emailed to multiple sites or posted to a listserv without the copyright holder's express written permission. However, users may print, download, or email articles for individual use. 